\title{
Erratum to: Mother-Stranger Comparisons of Social Attention in Jealousy Context and Attachment in HFASD and Typical Preschoolers
}

Nirit Bauminger-Zviely • Dana Shoham Kugelmass

Published online: 20 January 2013

(C) Springer Science+Business Media New York 2013

Erratum to: J Abnorm Child Psychol

DOI 10.1007/s10802-012-9664-1

The original version of the article was published with error in the spelling of the last name of the first author. Zvieli should have been spelled as Zviely as shown above.

The online version of the original article can be found at http://dx.doi.org/ 10.1007/s10802-012-9664-1.

N. Bauminger-Zviely $(\bowtie) \cdot$ D. S. Kugelmass

School of Education, Bar-Ilan University,

Ramat-Gan 52900, Israel

e-mail: nirit.bauminger@biu.ac.il 